\title{
Identification of Primary Container of Aedes Mosquitoes Breeding Site in Urban Region of Dengue Endemic Area, Purwokerto Indonesia
}

\author{
Identifikasi Kontainer Utama Tempat Perkembangbiakan Nyamuk Aedes di Wilayah \\ Perkotaan Daerah Endemis DBD, Purwokerto Indonesia
}

\author{
Siwi Pramatama Mars Wijayanti*, Devi Octaviana, Sri Nurlaela \\ Department of Public Health, Faculty of Health Sciences, Jenderal Soedirman University \\ Jalan dr. Soeparno, Kampus Karangwangkal, Purwokerto, Jawa Tengah, Indonesia \\ *E_mail: siwimars@gmail.com
}

Received date: 27-11-2019, Revised date: 17-11-2020, Accepted date: 18-11-2020

\begin{abstract}
Dengue prevention and control more reliant on reducing its vector, Aedes sp. mosquitoes by mosquito breeding nest eradication method. Therefore, identification of the primary container of the Aedes sp. breeding site particularly in the urban region of dengue-endemic area is a crucial effort to conduct an effective dengue prevention program. This research aimed to identify the primary container of the Aedes sp. breeding site in the urban region of the dengue-endemic area. This is a descriptive cross-sectional study, located in an urban region of dengue-endemic area within Banyumas Regency of Central Java Indonesia. A total of 300 houses in three urban areas were observed in urban areas of Purwokerto namely Arcawinangun, Purwanegara, and Karangpucung (100 houses each area). A total of 1504 water-holding containers were observed. All container was observed and recorded the type, color, lid condition, position, and the presence of mosquito larvae. The analysis was conducted by calculating the percentage of types, color, lid condition, and position of the container also the presence of mosquito larvae. The result of this study highlighted that flower pots and bathtubs were the primary types of containers with Aedes sp. larvae in the urban area. The characteristics of larvae-positive containers mostly open, bright, and located indoor position. Dengue prevention efforts by targeting the primary types of containers for mosquito breeding are expected to reduce the adult mosquito population.
\end{abstract}

Keywords: dengue, container, mosquitoes, Aedes sp.

\begin{abstract}
ABSTRAK
Upaya pencegahan dan penanggulangan Demam Berdarah Dengue (DBD) masih bergantung pada upaya menurunkan populasi vektor yakni nyamuk Aedes sp. dengan metode Pemberantasan Sarang Nyamuk (PSN). Oleh karena itu, identifikasi kontainer utama untuk perkembangbiakkan nyamuk Aedes sp. terutama di daerah endemis wilayah perkotaan penting dilakukan untuk pencegahan DBD yang efektif. Penelitian ini bertujuan untuk mengidentifikasi kontainer utama tempat perkembangbiakkan nyamuk Aedes sp. di daerah endemis wilayah perkotaan. Penelitian ini merupakan studi deskriptif dengan desain cross-sectional. Penelitian dilakukan di daerah endemis wilayah perkotaan, Purwokerto, Kabupaten Banyumas, Jawa Tengah, Indonesia. Observasi dilakukan pada 300 rumah di tiga wilayah perkotaan yakni Arcawinangun, Purwanegara dan Karangpucung (masing-masing area 100 rumah). Sebanyak 1504 kontainer air diamati pada penelitian ini. Setiap kontainer diamati dan dicatat tipe, warna, kondisi penutup, posisi, dan keberadaan larvanya. Analisis data dilakukan dengan menghitung persentase tipe kontainer, warna kontainer, kondisi tutup, lokasi kontainer, dan keberadaan larva. Hasil penelitian menunjukkan bahwa pot bunga dan bak kamar mandi merupakan kontainer utama perkembangbiakan nyamuk Aedes sp. di wilayah perkotaan. Karakteristik kontainer yang positif ditemukan larva Aedes sp. umumnya terbuka, berwarna terang, dan posisi berada di dalam rumah. Upaya pencegahan DBD dengan menarget kontainer utama tempat perindukan nyamuk diharapkan dapat menurunkan kepadatan nyamuk dewasa.
\end{abstract}

Kata kunci: dengue, kontainer, nyamuk, Aedes sp. 


\section{INTRODUCTION}

Dengue virus (DENV) infection is still considered as one of the important vectorborne diseases and public health concerns, particularly in tropical countries. ${ }^{1}$ This disease caused by the dengue virus which is transmitted by the female Aedes aegypti mosquito as the primary vector and Aedes albopictus as the secondary vector. ${ }^{2}$ Distribution of Ae. aegypti were observed to be concentrated in the tropical and sub-tropical parts of the world, while the ranges for $A e$. albopictus were found to extend into the temperate part of the world as well, especially in Southern Europe and the central USA. ${ }^{3}$ In Indonesia, 137,761 cases were registered in 2019, twice the amount reported in 2018. The incidence rates tend to be cyclical, peaking roughly every 6-8 years. ${ }^{4}$ Dengue caused a high economic burden for Indonesian public payers and society, with the total economic burden of dengue was estimated at US $\$ 381.15$ million which comprised US $\$ 355.2$ million for hospitalized and US\$26.2 million for ambulatory care cases in $2015 .{ }^{5}$ Several factors such as mosquito density, human mobility, demographic and socioeconomic factors could influence the DENV transmission. ${ }^{6,7}$

Until now, dengue prevention and control are more reliant on reducing its vector, Aedes sp. mosquitoes. Aedes aegypti is a primarily urban vector, prefer artificial containers as larval breeding sites and feeding almost exclusively on humans. While Ae. albopictus more often live in peri-urban and rural environments, feeding readily on a variety of mammalian (including humans) and avian species. $^{8}$ Various dengue prevention and control efforts have been carried out to reduce dengue cases in the community. The Indonesian government has carried out various programs, one of which is $3 \mathrm{M}$ plus (burying, closing, draining) that has been widely disseminated to the community in the mosquito breeding site eradication program. Identifying the primary container in certain areas indeed undoubtedly important for dengue prevention and control management. In the community, there are a relatively small number of containers that consistently serve as "primary containers" (the primary producers of Aedes larvae), while other containers playing minor roles in mosquito production. ${ }^{9}$ Productivity of a container type depends on a variety of factors, such as size and shape, the purpose of use, location (indoors, outdoors, under vegetation, etc.), lid status (covered/uncovered), the material with which the container is made (plastic, metal, cement/clay, etc.), temperature, availability of food, and competition among co-species. Moreover, each ecological setting has its own unique set of key containers. ${ }^{10}$

Moreover, each ecological setting has its own unique set of key containers, because the existence and type of containers are also influenced by local customs and culture. Previous studies in Bangladesh have shown that containers used to hold water, such as earthen jars, tanks, and drums, are the most common containers for larval breeding. ${ }^{9}$ While a study in Kuala Lumpur showed that the most common type of container was the plastic container. ${ }^{11}$ Because each area may have a different type of container, it is very important to know the main container in a certain area. This study was conducted in the urban area, Purwokerto, Banyumas Regency. By focusing on the containers that are most productive for Aedes sp. breeding site, control measures can be tailored for the specific needs of the area. This study aimed to identify the containers which served as primary producers of Aedes in the urban area. Characteristics of containers in the urban and rural areas show differences because of the variety of their ecology. The result of this study could provide important information about the key container of Aedes sp. therefore once the most productive key containers are identified, targeted control of dengue vectors becomes more affordable and feasible. In this study, three locations were taken in endemic areas of DHF in Banyumas Regency which showed a high number of cases, namely Arcawinangun village with 114 cases with 9 space praying/fogging times, 
Karangpucung with 92 cases and 4 times of fogging, and Purwanegara with 64 cases and 6 times of fogging. ${ }^{12}$

\section{METHOD}

\section{Research Design and Location of Study}

This is a descriptive study with a cross-sectional design conducted in three urban areas in Banyumas Regency, Central Java, Indonesia on June-September 2018. The location of this study was Arcawinangun, Purwanegara, and Karangpucung which are located in the administrative city of Purwokerto. The determination of research location was based on the high number of dengue cases in the area and its location in urban areas that are following the aims of this study. This data based on reports from the Banyumas district health office. The characteristics of the research area are urban regions of dengue-endemic areas in accordance with the research objectives.

\section{Samples and Data Collection}

One hundred houses in each area (total of 300 houses) in the study area were included in this research. The number of samples refers to a previous study. ${ }^{13}$ Sampling was carried out by proportional random sampling in each observed area. Surveys at each house were carried out by checking all containers, whether artificial or natural, in and around the house and the existence of mosquito larvae. Inspection of mosquito larvae is carried out with the help of a flashlight and a larva collection bottle. Data collection included types, the presence of mosquito larvae, the presence or absence of water, the condition of the lid, the color, and location of the container. The colors of the containers are divided into two categories, namely dark and bright. The dark container color category includes black, blue, and gray, while light colors include red, yellow, green, and similar color derivatives. Data retrieval was conducted with the help of observation sheets.

\section{Data Analysis}

The analysis was conducted by calculating the percentage of container types, the presence of mosquito larvae, the presence or absence of water, the condition of the lid, the color, and location of the container. Proportion infested is calculated based on observed containers divided by containers positive for larvae. The results of the analysis were presented in tables and graphs.

\section{Ethical Statement}

Studies conducted here were carried out with ethical approval from The Faculty of Medicine Jenderal Soedirman University, Medical and Health Research Ethics Committee Number 1914/UN23.07.5.1/PP.1/2018.

\section{RESULT}

To observe containers which potential as breeding sites for Aedes sp. mosquitoes, we conducted observations in 300 houses in 3 areas (Arcawinangun, Purwanegara, and Karangpucung). All the water-holding containers were recorded and the presence/absence of Aedes sp. larvae/pupae were inspected. Based on container observation in each house, we recorded containers by type and calculated the proportion of infested containers. Detail of water-holding container proportion could be seen in Table 1. 
Table 1. The Proportion of Water-Holding Containers Infested with Larvae and/or Pupae in the Three Villages of the Study Area

\begin{tabular}{|c|c|c|c|c|c|c|c|c|c|c|}
\hline \multirow{2}{*}{$\begin{array}{l}\text { Type of water- } \\
\text { holding } \\
\text { container }\end{array}$} & \multicolumn{2}{|c|}{ Arcawinangun } & \multirow{2}{*}{$\begin{array}{c}\text { Proport } \\
\text { ion } \\
\text { infested } \\
(\%)\end{array}$} & \multicolumn{2}{|c|}{ Purwanegara } & \multirow{2}{*}{$\begin{array}{c}\text { Proport } \\
\text { ion } \\
\text { infested } \\
(\%)\end{array}$} & \multicolumn{2}{|c|}{ Karangpucung } & \multirow{2}{*}{$\begin{array}{c}\text { Proport } \\
\text { ion } \\
\text { infested } \\
(\%)\end{array}$} & \multirow{2}{*}{$\begin{array}{c}\text { Total } \\
\text { proport } \\
\text { ion } \\
\text { infested } \\
(\%)\end{array}$} \\
\hline & $\begin{array}{l}\text { Obse } \\
\text { rved }\end{array}$ & $\begin{array}{l}\text { Positi } \\
\text { ve }\end{array}$ & & $\begin{array}{l}\text { Obser } \\
\text { ved }\end{array}$ & $\begin{array}{l}\text { Posi } \\
\text { tive }\end{array}$ & & Observed & $\begin{array}{l}\text { Positiv } \\
\text { e }\end{array}$ & & \\
\hline $\begin{array}{l}\text { Traditional bath } \\
\text { tub }\end{array}$ & 30 & 4 & 13.33 & 63 & 5 & 7.94 & 79 & 4 & 5.06 & 7.56 \\
\hline Buckets & 344 & 7 & 2.03 & 328 & 10 & 3.05 & 373 & 5 & 1.34 & 2.11 \\
\hline Dispenser & 8 & 0 & 0.00 & 23 & 0 & 0.00 & 8 & 1 & 12.50 & 2.56 \\
\hline Used bottles & 5 & 0 & 0.00 & 30 & 0 & 0.00 & 32 & 0 & 0.00 & 0.00 \\
\hline Refrigerator & 13 & 1 & 7.69 & 28 & 0 & 0.00 & 15 & 0 & 0.00 & 1.79 \\
\hline Flower pot & 8 & 1 & 12.50 & 10 & 2 & 20.00 & 18 & 0 & 0.00 & 8.33 \\
\hline Discarded tires & 0 & 0 & 0.00 & 0 & 0 & 0.00 & 10 & 0 & 0.00 & 0.00 \\
\hline Others & 30 & 6 & 20.00 & 19 & 0 & 0.00 & 36 & 0 & 0.00 & 7.06 \\
\hline Total & 432 & 19 & & 501 & 17 & & 571 & 10 & & \\
\hline
\end{tabular}

A total of 1504 water-holding containers were observed in this study. Based on Table 1 , the bucket is the most common water-holding container observed in all three villages (344 in Arcawinangun, 328 in Purwanegara, and 373 in Karangpucung). However, when looking at the proportion of larvae, we found that bathrooms and flower pots are the most productive container contained larvae in Arcawinangun and Purwanegara. While in Karangpucung, the most positive amount of larvae was in the dispenser and bathtub.

We also observed the condition of the positive container such as the lid, color, and position. The summary of the container with positive larvae condition could be seen in Table 2.

Based on Table 2, the characteristics of positive containers found in this study were mostly open, bright, and located in an indoor position.

Table 2. Condition of Positive Containers in the Study Area

\begin{tabular}{lllllll}
\hline & \multicolumn{2}{l}{ Lid condition $(\%)$} & \multicolumn{2}{l}{ Color $(\%)$} & & \multicolumn{2}{l}{ Position $(\%)$} \\
Villages & Open & Closed & Dark & Bright & Outdoor & Indoor \\
\hline Purwanegara & 94.12 & 5.88 & 29.41 & 70.59 & 47.06 & 52.94 \\
Arcawinangun & 73.68 & 26.32 & 47.37 & 52.63 & 21.05 & 78.95 \\
Karangpucung & 70 & 30 & 40 & 60 & 20 & 80 \\
\hline
\end{tabular}




\section{DISCUSSION}

Indonesian community has a habit of storing water for daily needs such as drinking water supplies, cooking, and bathing so that every house has many water-holding containers at home. ${ }^{4}$ This habit leads to a large number of water-holding containers in each house which can potentially become a mosquito breeding site. In this study, we calculated that the average container observed in three villages around 4-6 containers in each house (Arcawinangun $=4.32$, Purwanegara $=$ 5.01, and Karangpucung $=5.71$ ). From this study, the bucket was the most common containers found in the study area, followed by a traditional bathtub. Although present in large numbers, buckets did not contribute much to more larval production. This is possible because the volume of water stored in the bucket is not much, so it is used up more often. This is not suitable for breeding Aedes sp. mosquitoes which prefer to lay their eggs in stagnant water. $^{14}$ Previous research also mentioned that containers greater than 50 liters (L) are likely to produce 4.9 times more pupae than containers with $<1$ litre. $^{10}$ That facts could be explained why buckets with a large number in houses, however, showed less productive containers for Aedes sp. breeding site.

Based on Table 1, the total mean of the most productive container in three villages was flower pot (8.33\%), followed by a traditional bath up (7.56\%). This result following previous research which found that flower pots were the principal type of container with Ae. aegypti larvae. ${ }^{15}$ Flower pots are likely to be used as the breeding site of Aedes sp. mosquito because there is standing water in the long period. The house owner is also often unaware of the water in the flower pot, which makes this condition is conducive for the female adult mosquito to lay their eggs. Containers that preserved water for a long duration of time make suitable breeding habitats for Aedes sp. ${ }^{16}$ This should be a concern because this type of container does not receive attention when checking the larva's regular presence by larval monitoring cadres.

In this study, we also found that the traditional bathtub is the primary container for Aedes sp. breeding sites. Indonesian people have a habit of storing water for bathing. Usually, the water is stored for a long period. If the community is not routine in draining and replacing the water, then the place becomes a potential breeding place for mosquitoes. This is following the previous finding that stored water in the container for a long period, extended rainfall during the last rainy season, and ambient relative humidity and temperature may favor the breeding of Ae. aegypti mosquitoes. ${ }^{17}$ This varies from the circumstances of many countries that do not have the practice of storing water and using a shower for bathing.

There were more artificial containers than natural containers because this research was conducted in the urban area. Characteristics of urban areas with higher socioeconomic conditions, denser inhabitants are possible to influence the type of containers in the house. The finding of this study is also supported by the previous finding that Aedes aegypti tends to prefer artificial containers compared to natural containers for their breeding site. ${ }^{18}$

The results of the study also indicated that most positive container larvae had an open characteristic. The condition of the open container will allow the female Aedes sp. mosquitoes to lay their eggs on the surface of the container. Aedes sp. mosquitoes have a habit of putting eggs slightly above the water level in a container. ${ }^{19}$ Based on the color of the container, the results of this study were in contrast to previous studies which mentioned Aedes sp. mosquitoes prefer to lay eggs on dark-colored containers rather than bright ones. ${ }^{20}$ However, changes in mosquito preferences in oviposition could occur. Based on previous research, several factors could influence the oviposition preference of Aedes sp. such as the presence of conspecific larvae and pupae, container fill method, sun 
exposure, container size, and the presence of a lid. ${ }^{21}$ For location preferences, Ae. aegypti prefers clean water found in many types of domestic containers inside or near human dwellings, whereas Ae. albopictus is more likely to be found in natural containers or outdoor man-made habitats containing an abundant amount of organic debris. ${ }^{22}$

The limitation of this research is that this study only includes identification of the primary container, without examining its relationship with dengue cases in the study area. Larval density per container, as well as the examination of the dengue virus in larvae, were also not observed. Artificial and natural containers have not been categorized in this report. This is because the site of the study is an urban area with the characteristics that most containers are artificial containers.

\section{CONCLUSION}

The key findings of this study highlighted that flower pots and bathtub were the primary types of container for Ae. aegypti larvae. The characteristics of positive containers found in this study were mostly open, bright, and located in an indoor position.

\section{RECOMMENDATION}

Information from this study suggested that The community should pay attention to the main container, which often contains a lot of larvae, such as flower vases and bathtubs. By targeting the most productive container types, the adult mosquito density could decrease over time. In addition, regular checking for standing water can help reduce the presence of Aedes sp. larvae.

\section{AUTHOR CONTRIBUTIONS}

In this study, SPMW was the main writer responsible for conducting the research as well as writing the draft manuscript. SN assists in data analysis and displays the research results, while DO assists in coordinating field enumerators and provides input on writing research manuscripts. All authors are involved in the article publication process

\section{ACKNOWLEDGMENT}

We acknowledge the University of Jenderal Soedirman for funding this research (Grant 2496/UN23.14/PN/2018). We also thank the student of the public health department for their help on field data collection.

\section{REFERENCES}

1. Halstead S. Recent advances in understanding dengue. F1000Res. 2019;8:F1000 Faculty Rev-279. doi:

10.12688/f1000research.19197.1.

2. Medeiros AS, Costa DMP, Branco MSD, Sousa DMC, Monteiro JD, Galvão SPM, et al. Dengue virus in Aedes aegypti and Aedes albopictus in urban areas in the state of Rio Grande do Norte, Brazil: Importance of virological and entomological surveillance. PloS one. 2018;13(3):e0194108-e. doi: 10.1371/journal.pone.0194108.

3. Leta S, Beyene TJ, De Clercq EM, Amenu K, Kraemer MUG, Revie CW. Global risk mapping for major diseases transmitted by Aedes aegypti and Aedes albopictus. International journal of infectious diseases : IJID: official publication of the International Society for Infectious Diseases. 2018;67:2535. doi: 10.1016/j.ijid.2017.11.026.

4. Harapan H, Michie A, Mudatsir M, Sasmono RT, Imrie A. Epidemiology of dengue hemorrhagic fever in Indonesia: analysis of five decades data from the National Disease Surveillance. BMC Research Notes. 2019;12(1):350. doi: 10.1186/s13104-0194379-9.

5. Nadjib M, Setiawan E, Putri S, Nealon J, Beucher S, Hadinegoro SR, et al. Economic burden of dengue in Indonesia. PLoS neglected tropical diseases. 2019;13(1):e0007038-e. doi: 10.1371/journal.pntd.0007038.

6. Wijayanti SPM, Porphyre T, Chase-Topping M, Rainey SM, McFarlane M, Schnettler E, et al. The importance of socio-economic versus environmental risk factors for reported dengue cases in Java, Indonesia. PLoS neglected tropical diseases. 2016;10(9):e0004964-e. doi: 10.1371/journal.pntd.0004964. 
7. Wesolowski A, Qureshi T, Boni MF, Sundsøy PR, Johansson MA, Rasheed SB, et al. Impact of human mobility on the emergence of dengue epidemics in Pakistan. Proceedings of the National Academy of Sciences of the United States of America. 2015;112(38):11887-92. doi: 10.1073/pnas.1504964112.

8. Kraemer MUG, Sinka ME, Duda KA, Mylne A, Shearer FM, Brady OJ, et al. The global compendium of Aedes aegypti and Ae. albopictus occurrence. Scientific Data. 2015;2:150035. doi: 10.1038/sdata.2015.35.

9. Ferdousi F, Yoshimatsu S, Ma E, Sohel N, Wagatsuma Y. Identification of essential containers for Aedes larval breeding to control dengue in Dhaka, Bangladesh. Tropical medicine and health. 2015;43(4):253-64. doi: 10.2149/tmh.2015-16.

10. Islam S, Haque CE, Hossain S, Rochon $\mathrm{K}$. Role of container type, behavioural, and ecological factors in Aedes pupal production in Dhaka, Bangladesh: an application of zeroinflated negative binomial model. Acta tropica. 2019;193:50-9.

doi: 10.1016/j.actatropica.2019.02.019.

11. Mahmud M, Mutalip H, Lodz NA, Shahar H. Study on key Aedes spp. breeding containers in dengue outbreak localities in Cheras district, Kuala Lumpur. International Journal of Mosquito Research. 2018;5.

12. Banyumas Health Office. Profil Dinas Kesehatan Kabupaten Banyumas tahun 2018 2018. Available from: http://dinkes.banyumaskab.go.id/read/28410/pr ofil-kesehatan-tahun-2018-kabupatenbanyumas\#.X8YBEmgzY2w.

13. Wijayanti SPM, Sunaryo S, Suprihatin S, McFarlane M, Rainey SM, Dietrich I, et al. Dengue in Java, Indonesia: relevance of mosquito indices as risk predictors. PLOS Neglected Tropical Diseases. 2016;10(3):e0004500. doi: 10.1371/journal.pntd.0004500.

14. Nasir S, Jabeen F, Abbas S, Nasir I, Debboun M. Effect of climatic conditions and water bodies on population dynamics of the dengue vector, Aedes aegypti (Diptera: Culicidae). Journal of arthropod-borne diseases. 2017;11(1):50-9.

15. Williamson D, Jeffrey Gutierrez E, Ernst KC, Carrière Y, Walker KR, Reyes-Castro PA, et al. Socioeconomic and human behavioral factors associated with Aedes aegypti (Diptera: Culicidae) immature habitat in Tucson, AZ. Journal of Medical Entomology. 2018;55(4):955-63. doi: 10.1093/jme/tjy011.

16. Getachew D, Tekie H, Gebre-Michael T, Balkew M, Mesfin A. Breeding sites of Aedes aegypti: potential dengue vectors in Dire Dawa, East Ethiopia. Interdisciplinary perspectives on infectious diseases. 2015;2015:706276-. $10.1155 / 2015 / 706276$.

17. Abílio AP, Abudasse G, Kampango A, Candrinho B, Sitoi S, Luciano J, et al. Distribution and breeding sites of Aedes aegypti and Aedes albopictus in 32 urban/periurban districts of Mozambique: implication for assessing the risk of arbovirus outbreaks. PLoS neglected tropical diseases. 2018;12(9):e0006692-e. doi: 10.1371/journal.pntd.0006692.

18. Cardo MV, Rosín P, Carbajo AE, Vezzani D. Artificial container mosquitoes and first record of Aedes aegypti in the islands of the Paraná Lower Delta, Argentina. Journal of AsiaPacific Entomology. 2015;18(4):727-33. doi: https://doi.org/10.1016/j.aspen.2015.09.002.

19. Gonzalez PV, Gonzalez Audino PA, Masuh HM. Oviposition Behavior in Aedes aegypti and Aedes albopictus (Diptera: Culicidae) in response to the presence of heterospecific and conspecific larvae. J Med Entomol. 2016;53(2):268-72. doi: 10.1093/jme/tjv189.

20. Wong J, Stoddard ST, Astete H, Morrison AC, Scott TW. Oviposition site selection by the dengue vector Aedes aegypti and its implications for dengue control. PLOS Neglected Tropical Diseases. 2011;5(4):e1015. doi: 10.1371/journal.pntd.0001015.

21. Gunathilaka N, Ranathunge T, Udayanga L, Wijegunawardena A, Abeyewickreme W. Oviposition preferences of dengue vectors; Aedes aegypti and Aedes albopictus in Sri Lanka under laboratory settings. Bulletin of entomological research. 2018;108(4):44250.DOI: $10.1017 / \mathrm{s} 0007485317000955$.

22. Abreu FVSd, Morais MM, Ribeiro SP, Eiras ÁE. Influence of breeding site availability on the oviposition behaviour of Aedes aegypti. Memórias do Instituto Oswaldo Cruz. 2015;110:669-76 
BALABA Vol. 16 No. 2, Desember 2020: 181-188 